\title{
Gliding arc discharge-assisted biodegradation of crystal violet in solution with Aeromonas hydrophila strain
}

\author{
A. Njiki ${ }^{1}$ - G. Kamgang-Youbi ${ }^{1} \cdot$ S. Laminsi ${ }^{1}$ - C. D. Lontsi ${ }^{2}$ G. Payom ${ }^{1}$ \\ M. Nola ${ }^{2}$ E. Ngameni ${ }^{3}$
}

Received: 4 March 2015/Revised: 30 June 2015/Accepted: 14 July 2015 / Published online: 12 August 2015

(C) Islamic Azad University (IAU) 2015

\begin{abstract}
The gliding arc discharge, which is a source of nonthermal plasma, was used to enhance the biodegradation of crystal violet (CV), a triphenylmethane nonbiodegradable organic dye. The determination of the biodegradability index, i.e., biochemical oxygen demand $\left(\mathrm{BOD}_{5}\right) /$ chemical oxygen demand $(\mathrm{COD})$ ratio, and the total organic carbon measurement were used to assess the biodegradability. For the biological treatment alone, a bacterial strain of Aeromonas hydrophila $\left(8 \times 10^{8}\right.$ CFU mL ${ }^{-1}$ ) bleached $42 \%$ of $\mathrm{CV}$ solution $\left(50 \mathrm{mg} \mathrm{L}^{-1}\right)$ after $12-\mathrm{h}$ incubation. The bleaching rate was enhanced by increasing the initial bacterial concentration; however, a drop in the bleaching rate was noted when $\mathrm{CV}$ concentration was increased. For the plasma process alone, a 15-min treatment resulted in a color removal of $49.7 \%$, at a mineralization rate of $12.2 \%$, thereby increasing the $\mathrm{BOD}_{5} / \mathrm{COD}$ ratio from 0.11 to 0.23 . There was an increase in the bleaching rate in temporal post-discharge conditions (i.e., self-continuity of reaction after the discharge was
\end{abstract}

S. Laminsi

samuellaminsi@gmail.com

1 Laboratory of Mineral Chemistry, Department of Inorganic Chemistry, University of Yaounde I, P.O. Box 812, Yaoundé, Cameroon

2 Hydrobiology and Environment Research Unit, Department of Animal Physiology, University of Yaounde I, P.O. Box 812, Yaoundé, Cameroon

3 Laboratory of Analytical Chemistry, Department of Inorganic Chemistry, University of Yaounde I, P.O. Box 812, Yaoundé, Cameroon switched off): For $2 \mathrm{~h}$ of temporal post-discharge reaction, the color removal of the 15-min plasma-pre-treated $\mathrm{CV}$ increased to $55 \%$. The disappearance of color during each treatment method followed the first-order kinetics. With regard to the combined plasma/biological treatment process, the 15-min plasma-pre-treated sample was bleached at $92 \%$ by $A$. hydrophila after 2-h incubation and completely bleached for $6 \mathrm{~h}$. Therefore, there is a positive synergism of bacterial and plasma treatments. This combined treatment is useful in reducing the energy involved in complete mineralization of wastewater containing nonbiodegradable dyes.

Keywords Aeromonas hydrophila $\cdot$ Biodegradability enhancement · Bleaching - Coupling treatment system . Crystal violet $\cdot$ Glidarc plasma

\section{Introduction}

It is well known that organic dyes are a source of serious environmental contamination; approximately $10 \%$ of dyes used in industries are found in effluents (Young and $\mathrm{Yu}$ 1997). The removal of dyes from wastewaters is currently the subject of considerable investigation. Numerous techniques (physical, chemical, and biological/ biochemical, or a combination of two or more techniques) have been reported for the treatment of wastewater contaminated by organic dyes. The purpose of this paper was the application of a new coupling method to the degradation of crystal violet (CV) molecule, a triphenylmethane (TPM) dye, selected as recalcitrant nonbiodegradable organic model. $\mathrm{CV}$ is used in human and veterinary medicine as biological stains. As other TPM dyes, CV is also involved in paper, food, cosmetic, and 
rubber industries, and for coloring of oils, lipids, varnished plastics (Chiing-Chang et al. 2007; Mittal et al. 2010; Parshetti et al. 2011). Due to its high aromatic content, which stabilizes the molecule, $\mathrm{CV}$ is poorly metabolized by microorganisms and has a long life in the environment (Moturi and Singaracharya 2009).

Effluents which have been polluted by CV could be treated efficiently by the use of classical chemical and physiochemical methods (precipitation, coagulation/flocculation, and adsorption). Nevertheless, they are not destructive, given that they transfer organic dyes from water to another phase, thus causing sometimes secondary pollution. Recently, an excellent overview on chemical treatment technologies for wastewater recycling was brought forth, and many methods were critically examined (Gupta et al. 2012a). In fact, biological/biochemical processes (biodegradation) can be used: they are less expensive, reliable, and produce less sludge. For example, microorganisms such as Agrobacterium radiobacter, Pseudomonas putida, Bacillus cereus, and Aeromonas hydrophila could degrade CV (Chiing-Chang et al. 2007; Deng et al. 2008; Ren et al. 2006a; Parshetti et al. 2011). Nevertheless, due to the poor biodegradability of TPM dyes, the biological process requires a relatively long incubation time (up to $86 \mathrm{~h}$ ). Mineralization remains incomplete after the process, and organic products are still obtainable at the end of the treatment (Parshetti et al. 2011). Hence, biological treatment processes used alone against textile effluents do not always yield satisfactory results.

The advanced oxidation processes (AOPs), which are based on the generation of active hydroxyl radicals $\mathrm{OH}$, are claimed to degrade numerous organic compounds (Mantzavinos and Psillakis 2004; Gupta et al. 2012b; Saleh and Gupta 2012; Arab et al. 2015). The gliding arc discharge (glidarc), a convenient source of nonthermal plasma, belongs to these AOPs: It operates close to atmospheric pressure and at room temperature. This plasma exhibits characteristics of both thermal and nonthermal plasma, thereby making interaction with matter similar to that of "quenched" plasma (Lesueur et al. 1988). With humid air as the working gas, ' $\mathrm{OH}$ and $\mathrm{NO}$ ' were identified and quantified by spectroscopy measurements as the principal radical species present in the glidarc plasma plume (Benstaali et al. 2002). Moreover, they are precursors of other active species (Brisset et al. 2008). The glidarc technique was successfully tested for the pollutant abatement of aqueous effluents, and several examples relevant to the elimination of dyes found in domestic and industrial wastewaters are reported in the literature: These include TPM dyes such as malachite green, CV, bromothymol blue, and bromophenol blue (Abdelmalek et al. 2006; Doubla et al. 2008; Djepang et al. 2014).

The aim of this study was to test a promising alternative for wastewater treatment: a combination of the biological/ biochemical process (an inexpensive method, which is not efficient enough when solutes are non-biodegradable) and glidarc (source of oxidizing species, which can be expensive if the treatment times become long). Indeed, a chemical pre-treatment of an AOP [mainly due to the production of powerful oxidizing agents such as $\mathrm{OH}$ $\left.\left(E_{\left(\cdot \mathrm{OH} / \mathrm{H}_{2} \mathrm{O}\right)}=2.8 \mathrm{~V} / \mathrm{SHE}\right)\right]$ may convert recalcitrant organic compounds to biodegradable intermediates, which are subsequently treated biologically; thus, the associated costs are reduced. For example, the photo-Fenton process has been combined with biological treatment to treat water polluted by pesticides (Vilar et al. 2012), and to improve the biodegradability index of organic effluents in order to enhance the efficiency of biochemical treatment (Asha et al. 2014). Lotio et al. (2014) were concerned about the ozonation process coupled with biological process to remove color, $\mathrm{COD}$, and total nitrogen of textile yarn dyeing effluents. To the best of our knowledge, there is no report of attempts to use glidarc plasma/biodegradation coupling for the bleaching and degradation of organic pollutants.

As literature reports that $\mathrm{CV}$ solutions could be bleached in the presence of bacteria and independently by exposing the dye solutions to glidarc plasma, the purpose of this paper was to verify the possibility of enhancing the biodegradability of CV by glidarc plasma. Subsequently, plasma-pre-treated wastewater was treated biologically by the A. hydrophila strain, which was selected as biological agent.

The glidarc treatment of solutions also favors the occurrence of post-discharge phenomena (i.e., a self-development of the chemical reactions in the solution after the discharge is switched off). Indeed, some of the active oxidizing species are long life water-soluble moieties and are responsible for temporal post-discharge reactions (TPDR) which develop in the target liquid isolated from the plasma reactor (Brisset et al. 2008). A typical example of TPDR is reported during the plasma-chemical treatment of methyl orange dye (Moussa et al. 2007). To avoid any confusion, the degradation of $\mathrm{CV}$ in post-discharge conditions was also investigated and compared to the coupling plasma/biological treatment.

This research was carried out between June 2013 and December 2014 at the Laboratory of Mineral Chemistry and the Hydrobiology and Environment Research Unit of University of Yaoundé I, Cameroon. Some analyses were 
carried out at the Laboratory of Experimental Bacteriology of Centre Pasteur du Cameroun.

\section{Materials and methods}

\section{Reagents}

\section{Crystal violet solution}

The selected dye, i.e., CV, is a classical TPM dye, i.e., tris(4-(dimethylamino)phenyl)methylium chloride $\left(\left[\left(\mathrm{H}_{3} \mathrm{C}\right)_{2}\right.\right.$ $\left.\left.\mathrm{N}-\left(\mathrm{C}_{6} \mathrm{H}_{4}\right)\right]_{2} \mathrm{C}=\left(\mathrm{C}_{6} \mathrm{H}_{4}\right)=\mathrm{N}^{+}\left(\mathrm{CH}_{3}\right)_{2}, \mathrm{Cl}^{-}\right)$, also referred as $\mathrm{CV}$ or methyl violet $10 \mathrm{~B}$. The reagent was obtained from Sigma-Aldrich (France) and used without further purification. In aqueous solution, the $\mathrm{CV}$ ( $\mathrm{pH}$ 5.4) has a blue-violet color with a maximum absorption band at $585 \mathrm{~nm}$. At pH 1, $\mathrm{CV}$ solution is green with maximum absorption bands at 420 and $620 \mathrm{~nm}$. The $\mathrm{pH}$ of the samples was adjusted with $\mathrm{H}_{2} \mathrm{SO}_{4}$ and $\mathrm{NaOH}$ solutions $1 \mathrm{M}$. The chemical oxygen demand $(\mathrm{COD})$, the biological oxygen demand $\left(\mathrm{BOD}_{5}\right)$, and the total organic carbon (TOC) values of the initial solution (50 $\mathrm{mg} \mathrm{L}^{-1}$ ) were 170,20 , and $41 \mathrm{mg} \mathrm{L}^{-1}$, respectively.

Microorganism strain, culture condition, and preparation of suspensions

The bacterial strain, A. hydrophila, is an anaerobic facultative and gram-negative bacterium. It was isolated from well water using the membrane filtration technique on ampicillin dextrin agar medium (Marchal et al. 1991; Clesceri et al. 2005). A. hydrophila was used in the stationary growth phase; it was cultured using the laboratory method (Lontsi et al. 2013). Briefly, using a platinum loop, bacterial colonies were removed from the test tube and introduced into $10 \mathrm{~mL}$ of sterilized $\mathrm{NaCl} 0.15 \mathrm{M}$ solution, followed by homogenization with a vortex. This suspension was centrifuged twice at $8000 \mathrm{r} / \mathrm{min}$ for $10 \mathrm{~min}$ at $10{ }^{\circ} \mathrm{C}$. The pellet was resuspended in $\mathrm{NaCl}$ solution $0.15 \mathrm{M}$. A volume of $1 \mathrm{~mL}$ of this bacterial suspension was introduced into $10 \mathrm{~mL}$ of sterilized peptone solution and incubated for $17 \mathrm{~h}$ at $37^{\circ} \mathrm{C}$ in static conditions; at this stage, A. hydrophila was in the stationary growth phase. Plate count agar (PCA) was used for the pre-culture; the nutrient broth was tryptic soy broth (TSB); and ampicillin dextrin agar (ADA) medium was used for the cell culture and enumeration.

After the culture, the bacterial cells were harvested by centrifugation at $8000 \mathrm{r} / \mathrm{min}$ for $10 \mathrm{~min}$ at $10{ }^{\circ} \mathrm{C}$ and resuspended in $\mathrm{NaCl}$ solution $0.15 \mathrm{M}$. Suspensions for the biodegradation experiments were obtained by adjusting the absorbance (or former optical density (OD)) at $600 \mathrm{~nm}$ to the desired values. The concentration of each bacterial suspension was determined by the counting method after culture on ADA medium (Rodier et al. 1996). Thus, each OD corresponds to a bacterial concentration in $\mathrm{CFU} \mathrm{mL} \mathrm{mL}^{-1}$.

\section{Biological treatment}

A volume of $1 \mathrm{~mL}$ of the bacterial suspension $0.8 \times 10^{9}-$ $\mathrm{CFU} \mathrm{mL}{ }^{-1}$ was inoculated into sterile $25-\mathrm{mL}$ test tubes containing $10 \mathrm{~mL}$ of nutrient broth and $1 \mathrm{~mL}$ of $\mathrm{CV}$ $\left(50 \mathrm{mg} \mathrm{L}{ }^{-1}\right.$ ), and incubated at $37^{\circ} \mathrm{C}$ in static conditions. For various incubation times $(0,3,5,6,9,12 \mathrm{~h})$, the tubes were removed from the incubator and centrifuged at $8000 \mathrm{r} / \mathrm{min}$ for $10 \mathrm{~min}$ at $10{ }^{\circ} \mathrm{C}$ to separate the bacterial biomass. The supernatant was used to study the bleaching of CV by measuring its absorbance at the maximum absorption wavelength $\left(\lambda_{\max }=585 \mathrm{~nm}\right)$ with a spectrophotometer of mark Spectro PC SN 400216. The concentration of CV $\left(\mathrm{mg} \mathrm{L}^{-1}\right)$ in the supernatant was determined from the calibration curve of the CV. Two types of controls were used: uninoculated sterile control and heat-killed control. The former, containing only nutrient broth, indicated the effect of medium components in decolorization, and the latter showed adsorption to cells. Heat-killed bacteria were obtained by autoclaving the bacterial suspensions at $120{ }^{\circ} \mathrm{C}$ for $15 \mathrm{~min}$. Bleaching at different initial concentrations of $\mathrm{CV}$ (10-100 $\left.\mathrm{mg} \mathrm{L}^{-1}\right)$ was performed with bacterial biomass of $0.8 \times 10^{9} \mathrm{CFU} \mathrm{mL}^{-1}$ at $37^{\circ} \mathrm{C}$ in the nutrient broth. The effect of bacterial concentration $\left(0-3 \times 10^{9} \mathrm{CFU} \mathrm{mL}^{-1}\right)$ was evaluated with the $\mathrm{CV}$ concentration of $50 \mathrm{mg} \mathrm{L}^{-1}$ at $37{ }^{\circ} \mathrm{C}$ in the nutrient broth.

The bleaching rate was calculated at different incubation times using the formula:

Bleaching $(\%)=\frac{\mathrm{Abs}_{0}-\mathrm{Abs}_{t}}{\mathrm{Abs}_{0}} \times 100$,

where $\mathrm{Abs}_{0}$ is the initial absorbance and $\mathrm{Abs}_{t}$ is the absorbance at the time $t$.

This formula is generally used to evaluate the dye decolorization for both biological processes (Ren et al. 2006a; Sun-Young et al. 2002) and plasma treatments (Merouani et al. 2013).

The bleaching experiments were performed in triplicate.

\section{Glidarc plasma pre-treatment}

The experimental apparatus is shown in Fig. 1, and has been described previously (Moussa et al. 2007; Djepang et al. 2014). Under operating conditions, an air compressor generated the feed gas. The air supplied $\left(800 \mathrm{~L} \mathrm{~h}^{-1}\right)$ passes through a tube containing distilled water before being 
Fig. 1 Experimental device of glidarc plasma

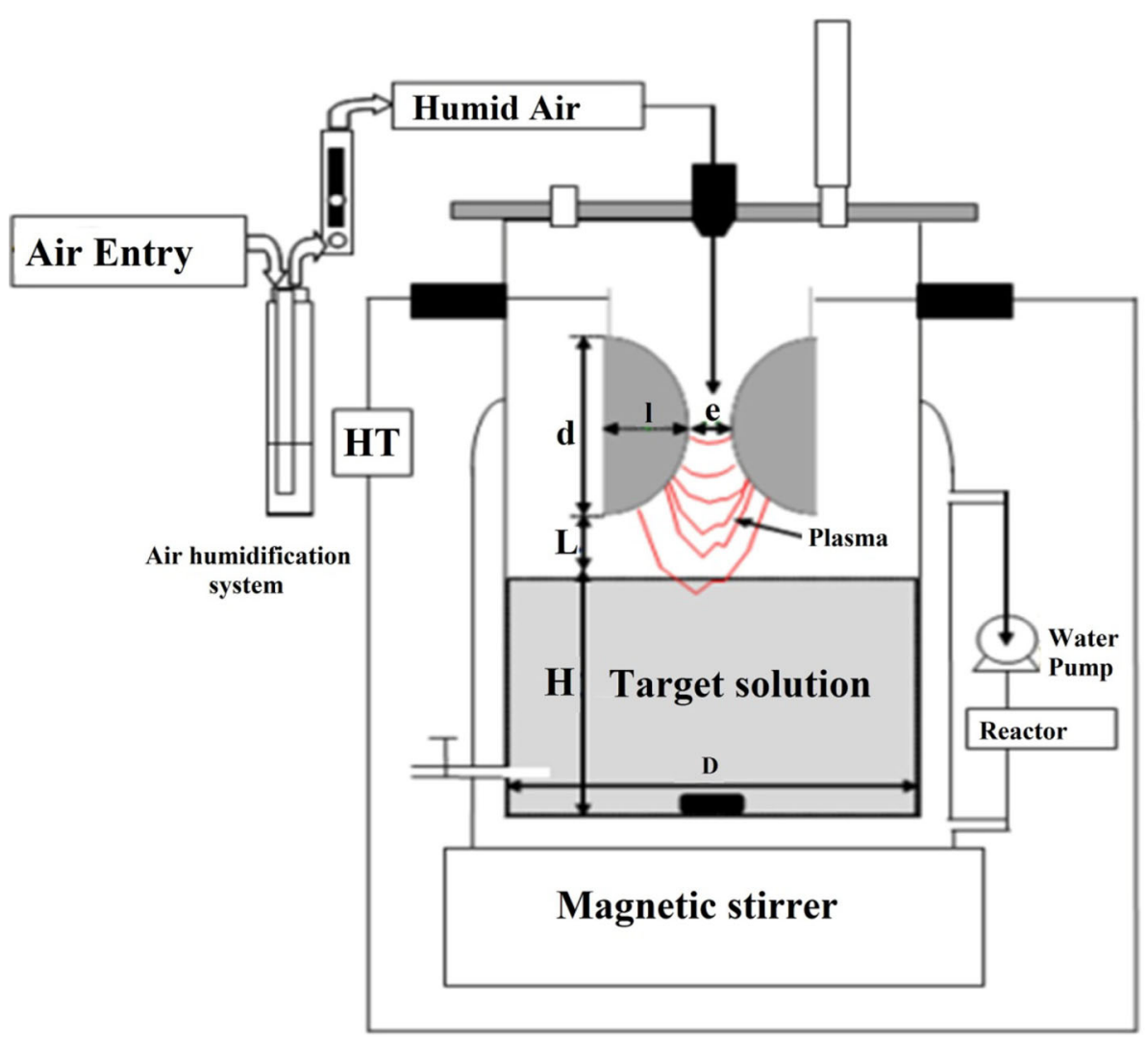

injected along the electrodes through a nozzle. The nozzle diameter was $1 \mathrm{~mm}$; the gap between the electrodes was $e=2 \mathrm{~mm}$; the distance between the tips of the electrodes and the top of target solution was $L=3 \mathrm{~cm}$; and the length of the electrodes was $d=6 \mathrm{~cm}$. For each set of experiment, about $450 \mathrm{~mL}$ of $\mathrm{CV}\left(50 \mathrm{mg} \mathrm{L}^{-1}\right)$ solution was introduced into the reactor as target solution, stirred magnetically, and exposed to glidarc humid air plasma. The solution is thermostatted at $25 \pm 2{ }^{\circ} \mathrm{C}$ by circulating water in a jacket. The plasma plume licks the surface of the target solution and allows chemical reactions to take place at the plasma solution interface. The treatment of the dye solution by the glidarc discharge was performed in the batch mode, and the residual concentration of $\mathrm{CV}$ for various exposure times $t^{*}(5,7,10,15,30 \mathrm{~min})$ was determined immediately after sampling with the spectrophotometer at $\lambda_{\max }=585 \mathrm{~nm}$, and bleaching rate was calculated according to Eq. (1).

The COD was determined by the potassium dichromate standard method, and the $\mathrm{BOD}_{5}$ was evaluated according to OECD-301F test using the OXITOP system (manometric respirometry) (Clesceri et al. 2005). TOC was measured with Shimadzu TOC analyzer equipped with an autosampler (ASI-5000) and platinum-based catalyst. TOC analyzer was calibrated with a standard solution of potassium hydrogen phthalate. The $\mathrm{PH}$ was measured using $\mathrm{pH}$ meter HANNA HI 9811-5 fitted with a glass electrode.

For temporal post-discharge treatments, the $\mathrm{CV}$ solutions were initially exposed to the discharge for $t^{*}=5$, 10 , and $15 \mathrm{~min}$, as described above. Once the discharge was switched off, the pre-treated solutions were left outside the reactor at the ambient temperature for various post-discharge times $t_{\mathrm{p}}(0-120 \mathrm{~min})$, and then, the analyses were performed as in the case of direct exposure of $\mathrm{CV}$ solution to a continuous discharge.

\section{Glidarc plasma/biological treatment coupling}

The CV solution (50 $\mathrm{mg} \mathrm{L}^{-1}$ ) was pre-treated with plasma in continuous discharge, i.e., by exposing the dye directly to the plasma plume, for various times $t^{*}(5,10$, and $15 \mathrm{~min}$ ). The determination of the biodegradability index, $\mathrm{BOD}_{5} / \mathrm{COD}$ and the $\mathrm{COD} / \mathrm{TOC}$ ratio, was used to evaluate the biodegradability of plasma-pre-treated $\mathrm{CV}$ solution. 
The plasma-pre-treated dye solution was used for the biological treatment with the A. hydrophila strain. Before this second step of coupling, the lethal effect of plasma (TPDR effects) was neutralized by adjusting the $\mathrm{pH}$ of the plasma-pre-treated solution at $\mathrm{pH} 6$ with $\mathrm{NaOH}$ solution (Naïtali et al. 2010).

\section{Results and discussion}

\section{Biodegradation of crystal violet by Aeromonas hydrophila}

\section{Effect of the state of bacterial cells on the bleaching}

The effect of the state of bacterial cells on the bleaching of $\mathrm{CV}$ by $A$. hydrophila is shown in Fig. 2. Under static conditions at $\mathrm{pH} 7.5$ and $37{ }^{\circ} \mathrm{C}$, A. hydrophila $\left(0.8 \times 10^{9}-\right.$ CFU mL ${ }^{-1}$ ) in stationary growth phase bleached $42 \%$ of CV (50 mg L ${ }^{-1}$ ) for 12 -h incubation. The uninoculated sample showed no evidence of bleaching, indicating that the nutrient broth and the incubator have no effect on the decolorization. These biodegradation results are comparable to those obtained by Chimezie and Sawidis (2011) who reported that $A$. hydrophila removes $30 \%$ of $\mathrm{CV}$ $\left(50 \mathrm{mg} \mathrm{L}^{-1}\right)$ at $30^{\circ} \mathrm{C}$ for $24 \mathrm{~h}$ of static incubation. $A$. radiobacter degraded $80 \%$ of a less concentrated $\mathrm{CV}$ solution (10 $\left.\mathrm{mg} \mathrm{L}^{-1}\right)$ within $8 \mathrm{~h}$ (Parshetti et al. 2011), while $P$. putida decolorized $80 \%$ of CV $\left(25 \mathrm{mg} \mathrm{L}^{-1}\right)$ after 7 days (Chiing-Chang et al. 2007). To investigate the mechanism of microbial decolorization by A. hydrophila, the

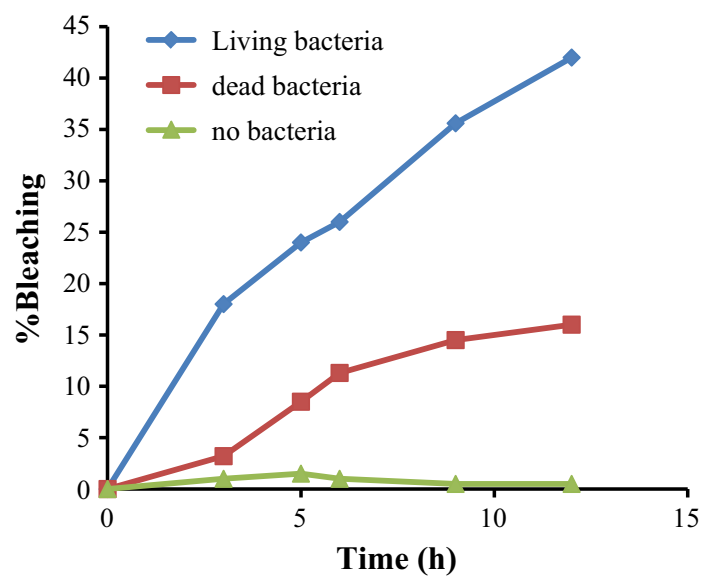

Fig. 2 Effect of the state of bacterial cells on bleaching, $T=37{ }^{\circ} \mathrm{C}$, pH 7.5 (A. hydrophila $)=0.8 \times 10^{9} \mathrm{CFU} \mathrm{mL}^{-1}$ control test with heat-killed bacteria is useful. Indeed, this experiment helps to attribute the degradation to the adsorption of dye molecules onto microbial biomass and/or to the biodegradation of dye by the cells (Zhou and Zimmermann 1993; Sani and Banerjee 1999; Sun-Young et al. 2002; Ren et al. 2006a). In both cases, decolorization results from a change in the electron distribution in the dye molecule, either due to biological processes involving enzymes, or due to the formation of new bonds between the dye and the solid adsorbent in the case of adsorption (Saleh et al. 2014). In case of adsorption, the bacterial cells appear colored, but maintain their original color in case of biodegradation (Ren et al. 2006a). In this study, the bacterial cells were slightly colored; therefore, a part of degradation could result from adsorption. To confirm this hypothesis, a bleaching rate by only $16 \%$ was obtained with heat-killed bacteria (Fig. 2), and this part was due to the adsorption. This bleaching rate corresponds to an increase in the pore surface area of the bacterial cells during autoclaving and then to the formation of new adsorption sites on the bacteria surface (Chen et al. 2003; Chimezie and Sawidis 2011; Ogugbue Chimezie et al. 2012). Hence, the bleaching rate resulting from adsorption caused by living bacteria in static condition should be very small.

However, a bleaching rate by $42 \%$ was obtained with living cells, which implies that the mechanism can be attributed mainly to bacterial metabolism. As demonstrated in previous works, the biodegradation of TPM dye is caused by a soluble cytosolic enzyme, NADH/NADPHdependent oxygenase secreted by A. hydrophila (Ren et al. 2006a, b; Ogugbue Chimezie et al. 2012), and is based on reduction and demethylation reactions (Parshetti et al. 2011). The color removal of $\mathrm{CV}\left(50 \mathrm{mg} \mathrm{L}^{-1}\right)$ by $A$. hydrophila in static condition, which is largely attributed to biodegradation, is relatively low ( $\leq 42 \%$ ) for 12 -h incubation and needs to be increased.

\section{Effect of bacterial concentration on the bleaching}

Bleaching of $\mathrm{CV}$ solution was studied as a function of the bacterial concentration of inoculum (Fig. 3). The bleaching trends are similar regardless the initial bacterial concentration. Generally, for each incubation time, the percentage of bleaching of $\mathrm{CV}$ (50 mg L $\left.{ }^{-1}\right)$ increased with the concentration of A. hydrophila. This is because the amount of enzyme secreted by bacteria increases with the cell concentration. Similar trends were obtained in previous works during the biodegradation of CV by A. radiobacter (Parshetti et al. 2011). After 9-h incubation, regardless of the bacterial 


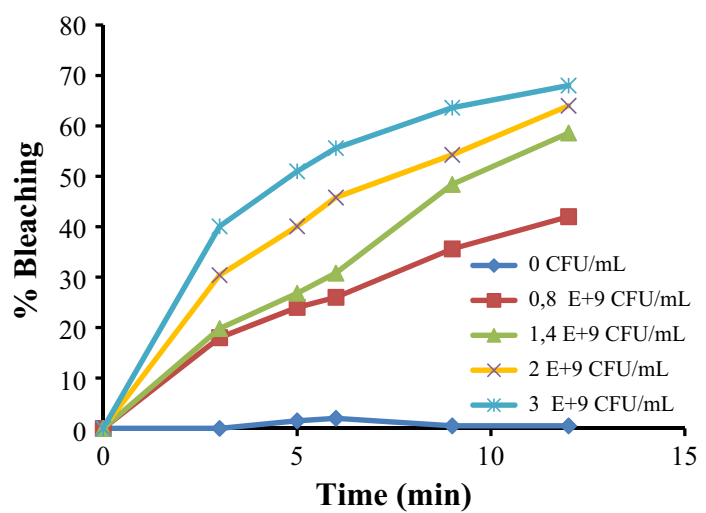

Fig. 3 Effect of bacterial concentration on bleaching of $\mathrm{CV}$, $T=37{ }^{\circ} \mathrm{C}(\mathrm{CV})=50 \mathrm{mg} \mathrm{L}^{-1}, \mathrm{pH} 7.5$

concentration, the bleaching rate increases slightly (Fig. 3) because of the low nutrient content of the medium.

The kinetic studies showed that the biodegradation of CV by A. hydrophila followed pseudo-first-order kinetics regardless of the initial bacterial concentration (not shown here). For example, with an initial bacterial concentration of $0.8 \times 10^{9} \mathrm{CFU} \mathrm{mL}^{-1}$ and dye concentration of $50 \mathrm{mg} \mathrm{L}{ }^{-1}$, the plot of $\ln \left(\mathrm{Abs}_{0} / \mathrm{Abs}_{t}\right)$ versus time (h) presented a linear plot with an average rate constant $k_{\mathrm{b}}=0.044 \mathrm{~h}^{-1}=7.33 \times 10^{-4} \mathrm{~min}^{-1}$ (the relevant coefficient $\left.R^{2}=0.985\right)$. The rate constant $k_{\mathrm{b}}\left(\mathrm{h}^{-1}\right)$ increased with the initial bacterial concentration $N_{0}\left(\mathrm{CFU} \mathrm{mL}{ }^{-1}\right)$ according to a reasonably linear relationship:

$k_{\mathrm{b}}=2.67 \times 10^{-11} N_{0}+0.0286 \quad\left(R^{2}=0.94\right)$

This finding confirms that the biodegradation of organic compounds at low concentrations generally follows firstorder kinetics (Feng et al. 2004; Siciliano and De Rosa 2015), which corroborates Durai et al.'s (2011) study of the biodegradation of tannery effluents in a batch bioreactor.

Although the bleaching rate could be enhanced by increasing the initial bacterial concentration, or even by considering the highest concentration used, the bleaching remains incomplete.

\section{Effect of pollutant concentration on bleaching}

The influence of the initial $\mathrm{CV}$ concentration $C_{0}$ on the biodegradation rate was also considered. With the same

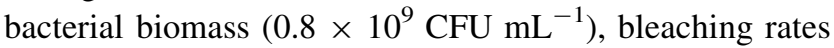
of $\mathrm{CV}$ decrease with increasing $C_{0}$ : Bleaching rates of 72 and $42 \%$ were obtained for 10 and $50 \mathrm{mg} \mathrm{L}^{-1}$ of $\mathrm{CV}$, respectively, for 12-h incubation (Fig. 4). However, between 50 and $100 \mathrm{mg} \mathrm{L}^{-1}$ of $\mathrm{CV}$, no significant change in the bleaching rate was observed. Rajesh and Uttam (1999) have

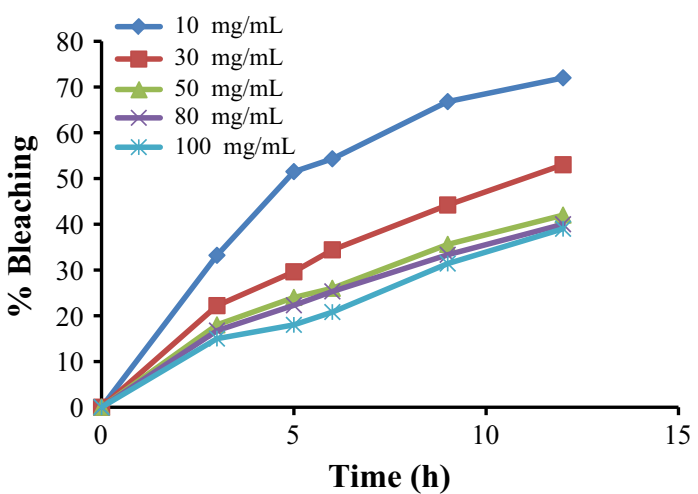

Fig. 4 Effect of initial concentration of $\mathrm{CV}$ on bleaching $\mathrm{T}=37{ }^{\circ} \mathrm{C}$ $($ A. hydrophila $)=0.8 \times 10^{9} \mathrm{CFU} \mathrm{mL}^{-1}, \mathrm{pH} 7.5$

also shown that the CV decolorization by Kurthia sp. decreased as the concentration of the dye increased. Above $50 \mathrm{mg} \mathrm{L}^{-1}$ of $\mathrm{CV}$, the metabolism of $A$. hydrophila cells was inhibited probably because the cells are in the stationary phase. On the contrary, other bacteria such as Citrobacter sp. and $B$. cereus, in the growth phase, have a high bleaching rate even with high concentrations of organic pollutants (SunYoung et al. 2002; Yousefi Kebria et al. 2009).

\section{Biodegradability enhancement of $\mathrm{CV}$ by glidarc plasma}

\section{Bleaching and degradation of $C V$ by direct exposure to a continuous discharge}

Direct exposure of the CV solution to the glidarc discharge for time $t^{*}$ (i.e., continuous discharge) was investigated previously by Abdelmalek et al. (2006) who was a pioneer in the plasma bleaching/degradation of dye-stuff. Figure 5 shows that the initial concentration of $\mathrm{CV}$ solution decreased during the plasma treatment. The initial $\mathrm{pH}$ of 5.4 decreases during the first minutes of treatment and remains around 3.5 throughout the treatment (not shown here), as observed in many earlier studies (Moussa et al. 2007; Doubla et al. 2008; Njoyim-Tamungang et al. 2009; Djepang et al. 2014). The degradation of the dye was followed by the determination of COD, and the bleaching was followed by residual concentration (absorbance). Figure 5 presents the evolution of these parameters. Bleaching and degradation occur simultaneously from the first few minutes of treatment. The bleaching rate was higher than the degradation rate especially during the first few minutes. For 5-min treatment, COD abatement was $13 \%$, while decolorization abatement was higher (two times the COD abatement), i.e., $28.5 \%$. For $t^{*}=30 \mathrm{~min}, 67 \%$ of 


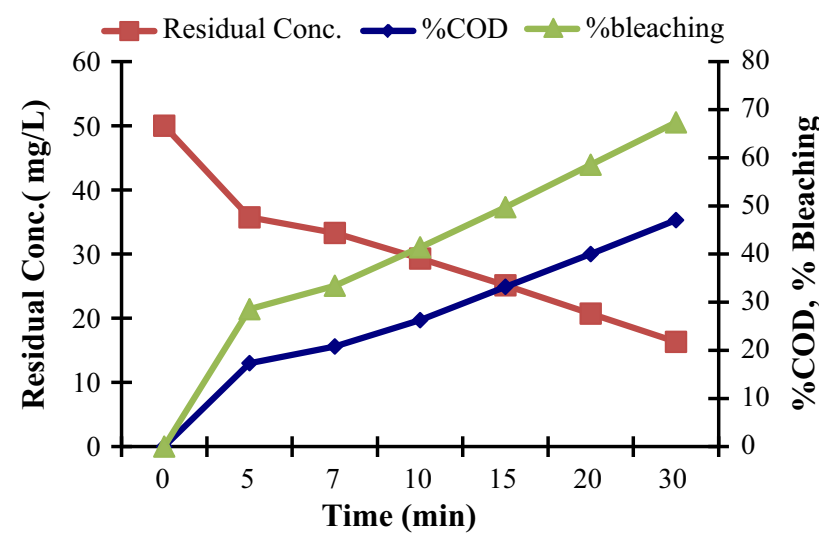

Fig. 5 Evolution of residual concentration, bleaching, and COD removal of $\mathrm{CV}$ during direct exposure of $\mathrm{CV}$ to discharge

bleaching and $35 \%$ of degradation were obtained (Fig. 5). This difference can be explained by the fact that bleaching results from the combined effects of acidification by plasma (due to the formation of transient nitrous acid and nitric acid) and oxidation by oxidizing agents such as primary species $\mathrm{HO} \quad\left(E_{\left(\cdot \mathrm{OH} / \mathrm{H}_{2} \mathrm{O}\right)}^{\cdot}=2.8 \mathrm{~V} / \mathrm{SHE}\right)$, and $\mathrm{NO}\left(E_{\left(\mathrm{NO}^{+} / \mathrm{NO}\right)}=\right.$ $1.21 \mathrm{~V} / \mathrm{SHE})$. Bleaching results from derivatives species: $\mathrm{H}_{2} \mathrm{O}_{2} \quad\left(E_{\left(\mathrm{H}_{2} \mathrm{O}_{2} / \mathrm{H}_{2} \mathrm{O}\right)}^{\cdot}=1.8 \mathrm{~V} / \mathrm{SHE}\right)$, peroxynitrous acid $\mathrm{ONOOH}\left(E_{\left(\mathrm{ONOOH} / \mathrm{NO}_{2}\right)}=2.02 \mathrm{~V} / \mathrm{SHE}\right)$, and peroxynitrites $\mathrm{ONOO}^{-}\left(E_{(\mathrm{NO} / \mathrm{ONOO}-)}=2.1 \mathrm{~V} / \mathrm{SHE}\right)$; while degradation is only caused by these oxidizing agents (Doubla et al. 2008; Iya-Sou et al. 2011; Merouani et al. 2013). These trends are similar to those obtained by Abdelmalek et al. (2006). Plasma decolorization is due to the cleavage of the $-\mathrm{C}=\mathrm{C}-$ and $-\mathrm{N}=\mathrm{C}-$ chromophore groups of the $\mathrm{CV}$ molecule, while degradation requires the cleavage of chromophore groups but also the opening of the aromatic rings and grafting of nitrogen containing groups provided by $\mathrm{ONOO}^{-}$(Brisset et al. 2008; Naïtali et al. 2012).

The bleaching and the degradation kinetics followed pseudo-first-order kinetics, obtained by the linear plots of the absorbance $\ln A_{585}$ and $\ln$ COD versus $t^{*}$ (not shown). The calculated rate constants were $k_{\text {ble }}=4.2 \times 10^{-2}$ $\min ^{-1} \quad\left(R^{2}=0.984\right) \quad$ and $\quad k_{\mathrm{deg}}=1.4 \times 10^{-2} \mathrm{~min}^{-1}$ $\left(R^{2}=0.964\right)$ for bleaching and degradation, respectively.

\section{Bleaching of crystal violet in post-discharge conditions}

CV samples were exposed to the gliding electric discharge for various times $t^{*}(5,10$, and $15 \mathrm{~min})$. After each exposure, the samples were disposed outside the plasma reactor and abandoned for times $t_{\mathrm{p}}(30,60,90$, and
$120 \mathrm{~min}$ ) in post-discharge conditions, i.e., in the absence of any extra energy source. The color removal of CV increased with post-discharge time. For exposure time $t^{*}=5 \mathrm{~min}$, the color abatement was $28.6 \%$ immediately after switching off the discharge $\left(t_{\mathrm{p}}=0 \mathrm{~min}\right)$; the rates were $32.5,34.5,37$, and $39 \%$ for $t_{\mathrm{p}}: 30,60,90$, and 120 min post-discharge, respectively (Fig. 6). The bleaching reaction during post-discharge also followed pseudofirst-order kinetics with an average rate constant of $1.67 \times 10^{-3} \mathrm{~min}^{-1}$ for $t^{*}=5 \mathrm{~min}$. The results presented in Fig. 6 confirm the occurrence of TPDR for the other exposure times $t^{*}(10$ and $15 \mathrm{~min}$ ).

Generally, the authors attribute the degradation in TPDR conditions to the species $\mathrm{H}_{2} \mathrm{O}_{2}$ and $\mathrm{HNO}_{2}$ formed in the discharge (Kamgang-Youbi et al. 2007; Moussa et al. 2007). The authors also consider the great influence of peroxynitrites $\mathrm{ONOO}^{-}$and its matching acid, which are soluble in water; able to dissociate into $\mathrm{OH}$ and $\mathrm{ONO}^{-}$; and to induce oxidizing, nitrating, and nitrosing post-discharge effects on solutes (Naïtali et al. 2012; Merouani et al. 2013).

It is important to know that the TPDR active species are $\mathrm{pH}$-dependent. Indeed, when the $\mathrm{pH}$ of the dye solution was not adjusted immediately after exposure $\mathrm{pH}$ around 3.5 ), the residual concentration of the target liquid decreased during post-discharge, meaning that bleaching and degradation evolve, as presented above. On the contrary, when the $\mathrm{pH}$ was adjusted to 6 , the concentration of $\mathrm{CV}$ remained constant during the post-discharge (Fig. 6). So, the $\mathrm{pH}$ can be used to neutralize reactive species responsible for the post-discharge phenomenon. This

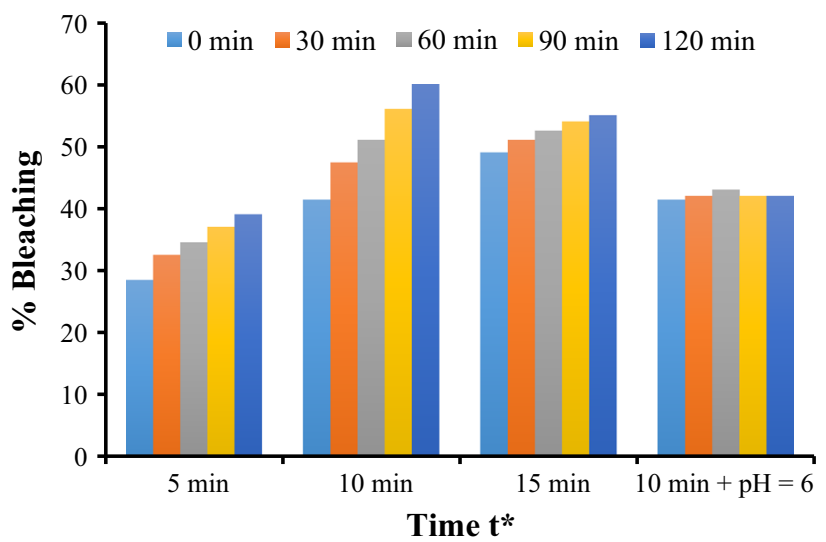

Fig. 6 Evolution of bleaching percentage and $\mathrm{pH}$ effect on reactivity of species $\left(t^{*}=10 \mathrm{~min}\right)$ during post-discharge treatment of $\mathrm{CV}$ $\left(t_{\mathrm{p}}=0-120 \mathrm{~min}\right)$ 
method was used by Naitali et al. (2010) to stop the lethal effect of the glidarc plasma on the microorganisms in TPDR conditions and can be used in this work in order to demonstrate the effectiveness of the second step of coupling.

\section{Effect of plasma on the biodegradability}

The evolution of COD, $\mathrm{BOD}_{5}$, and TOC during direct exposure of $\mathrm{CV}$ solution to the discharge is shown in Fig. 7. COD decreases from 170 to $110 \mathrm{mg} \mathrm{L}^{-1}$, and $\mathrm{BOD}_{5}$ increases from 20 to $40 \mathrm{mg} \mathrm{L}^{-1}$ for $30 \mathrm{~min}$ of glidarc treatment, meaning that there is a conversion of the COD to BOD $_{5}$. Marco et al. (1997) reported that the treatment of organic compounds such as 2,4-diclorophenol by an $\mathrm{AOP}$, ozonation, increases $\mathrm{BOD}_{5}$ from 0 to $55 \mathrm{mg} \mathrm{L}^{-1}$ after $60 \mathrm{~min}$ of treatment. A decrease in TOC from 41 to $32.5 \mathrm{mg} \mathrm{L}^{-1}$ was observed for $30 \mathrm{~min}$ of treatment with a TOC abatement of $20.7 \%$ indicating a low mineralization of CV. Abdelmalek et al. (2008) achieved only $19 \%$ of TOC abatement for 30-min degradation of bisphenol A by glidarc plasma. Therefore, the byproducts of $\mathrm{CV}$ degradation for $30 \mathrm{~min}$ of glidarc treatment are still organic compounds.

The evolution of the COD/TOC ratio and the biodegradability index $\mathrm{DBO}_{5} / \mathrm{COD}$ during the glidarc treatment of $\mathrm{CV}$ is shown in Fig. 8. The COD/TOC ratio provides information on the oxidation state of organic substances in solution (Marco et al. 1997). For alkanes, this parameter is between 4 and 5.3, while for strong oxidants such as oxalic acid, the value is 0.6 (Marco et al. 1997). During the plasma treatment, the COD/TOC ratio decreased, from 4.15 for the initial solution to 3.38 for

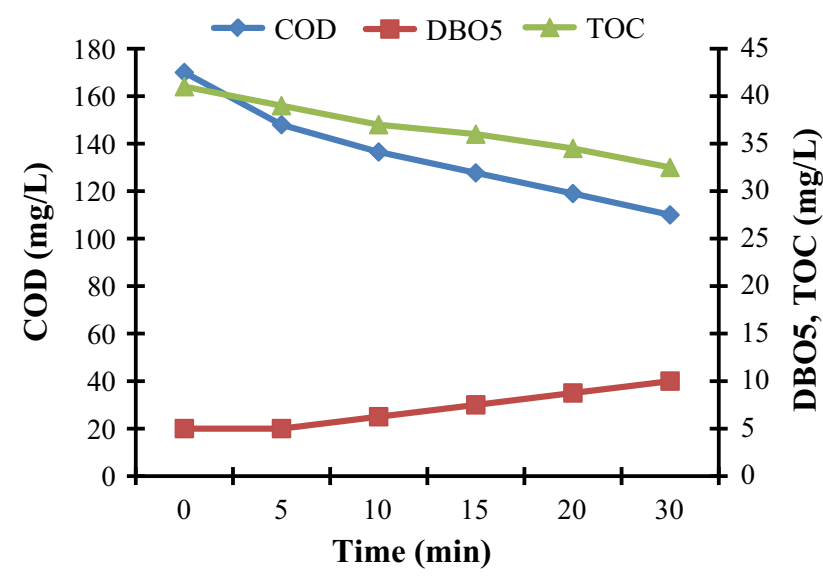

Fig. 7 Evolution of $\mathrm{COD}, \mathrm{DBO}_{5}$, TOC during plasma treatment of $\mathrm{CV}$ in continuous discharge

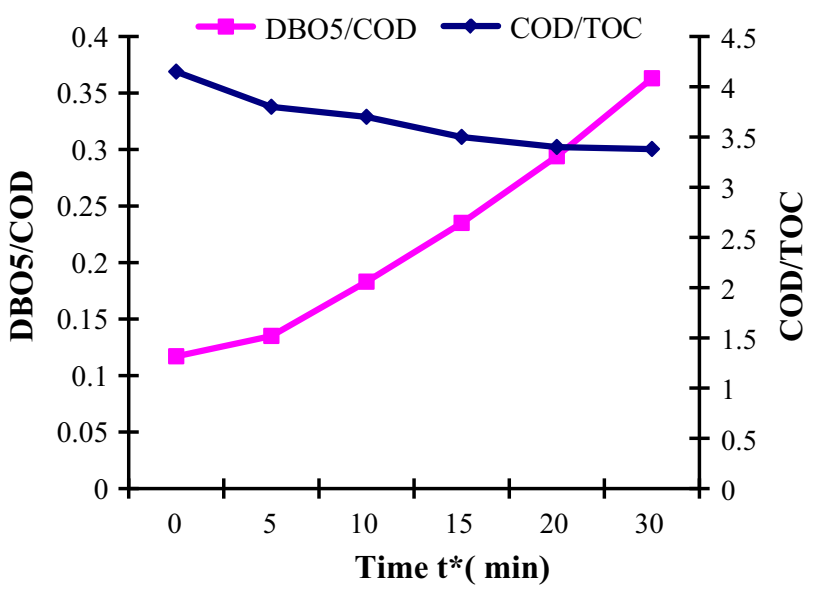

Fig. 8 Evolution of biodegradability index and COD/TOC ratio of CV during plasma treatment

$t^{*}=30$ min (Fig. 8). This decrease is due to the high oxidation degree of organic substances in solution. The biodegradability index $\mathrm{DBO}_{5} / \mathrm{COD}$ increased significantly during treatment, rising from 0.11 for the initial solution of $\mathrm{CV}$, to 0.36 for 30 -min treatment. Given that only the effluents with $\mathrm{DBO}_{5} / \mathrm{COD}$ ratio $\geq 0.33$ are considered as biodegradable (Goi et al. 2004; García-Montaño et al. 2006), the 30-min plasma-treated CV is therefore biodegradable. For $t^{*}<30 \mathrm{~min}$, the resulting effluents were not biodegradable. Indeed, for $t^{*}=5,10,15$, and $20 \mathrm{~min}$, the biodegradability indexes were $0.13,0.18,0.23$, and 0.29 , respectively. Although these values were $<0.33$ (for $t^{*}<30 \mathrm{~min}$ ), one can note that there is still an increase in biodegradability. Previous works also demonstrated that AOPs (ozonation, photocatalysis ...) increase biodegradability of non-biodegradable organic pollutants (Mantzavinos and Psillakis 2004; Farre et al. 2005; Zapata et al. 2010). Since mineralization was low (Fig. 7), the byproducts formed for $t^{*} \leq 30 \mathrm{~min}$ during plasma-chemical oxidation are biodegradable organic compounds or some species which are less biorecalcitrant than CV. Among the factors that contribute to the biodegradability enhancement, we can mention the partial mineralization of the pollutant molecule, the conversion of the aromatic to aliphatic compounds by ring-opening, ring-hydroxylation and detoxification (Goi et al. 2004; Khenniche et al. 2015). During the plasma treatment, strong oxidizing agents such as $\mathrm{OH}^{-}$and $\mathrm{NO}^{-}$(and derivatives) can attack at the aromatic rings causing ring-opening, or at the carbon in $\alpha$-position with respect to electrophilic central carbon of $\mathrm{CV}$ to yield the cleavage of conjugated chromophores structures. Carboxylic acids, N-aminobenzene, which are more biodegradable than the $\mathrm{CV}$ could be obtained inter alia 
(Huan-Jung et al. 2009). The aim of this section was not to demonstrate the reaction mechanism of degradation, but to assert merely that the degradation was due to glidarc oxidizing agents. Previous works reported that the $\mathrm{N}$-demethylation and cleavage of conjugated chromophore structures are plausible mechanisms of degradation of $\mathrm{CV}$ by Fenton processes (Huan-Jung et al. 2009). These authors have identified inter alia pararosaniline and the $4,4^{\prime}$-bisaminobenzophenone as by-products of $\mathrm{CV}$ degradation. Given that it is not necessary to pre-treat the $\mathrm{CV}$ for long durations, the plasma pre-treatment times of 5, 10, and 15 min could be used to study the glidarc plasma/ biodegradation coupling process.

\section{Plasma-chemical oxidation/biodegradation coupling}

\section{Glidarc direct exposure followed by biodegradation}

The evolution of the bleaching rate during the biodegradation by $A$. hydrophila $\left(0.8 \times 10^{9} \mathrm{CFU} \mathrm{\textrm {mL } ^ { - 1 }}\right)$ of the $\mathrm{CV}$ pretreated for various times $t^{*}$ with glidarc plasma is shown in Fig. 9. For 5-, 10-, and 15-min plasma treatment alone, the bleaching rates were $28.5,41.4$, and $49.7 \%$, respectively (0$\mathrm{h}$ incubation). After glidarc pre-treatment, the glidarc long life species were first neutralized with $\mathrm{NaOH}$ solution, and then, the biological treatment by A. hydrophila was carried out under the same conditions with no pre-treated samples (Fig. 2). For all pre-treated samples, the bleaching rates were higher than those obtained with the no pre-treated samples $\left(t^{*}=0 \mathrm{~min}\right)$. For example, the bleaching rates for 5-min plasma-pre-treated solution were $28.5,60,65$, and $70 \%$ for $0-, 2-, 4-$, and 6-h incubation, respectively, compared to the sample not pre-treated ( $t^{*}=0 \mathrm{~min}$ ), with bleaching rates 0 , 12,22 , and $26 \%$ for $0,2,4$, and $6 \mathrm{~h}$ of incubation, respectively (Fig. 9); there is an enhancement of biodegradation by glidarc. This enhancement was also evidenced for the other pre-treated samples (10 and $15 \mathrm{~min}$ ). For all pre-treated

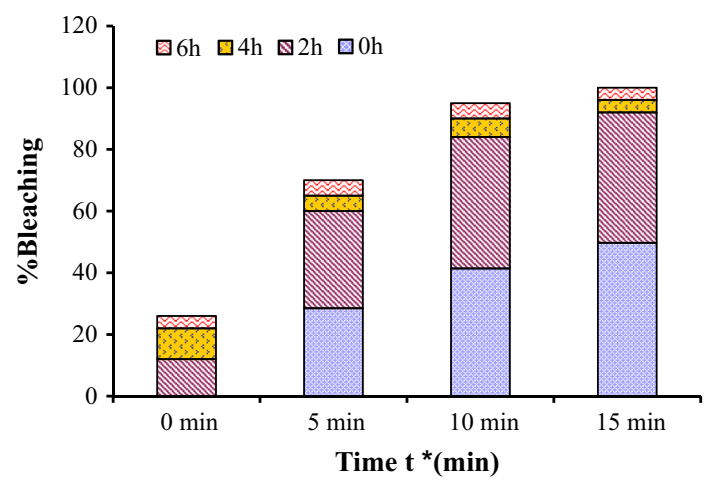

Fig. 9 Evolution of bleaching during biodegradation of $\mathrm{CV}$ pretreated with plasma at different time $t^{*}($ A. hydrophila $)=0.8 \times 10^{9}$ $\mathrm{CFU} \mathrm{mL}{ }^{-1}, T=37^{\circ} \mathrm{C}, \mathrm{pH} 7.5$ samples, the bleaching rate increased with the incubation time same as the samples directly treated by A. hydrophila without glidarc exposure. One also observed the influence of the glidarc exposure duration on bleaching rates during the biodegradation of plasma-pre-treated CV: For 2-h incubation, the values of the bleaching rate were enhanced by 31.5 , 42.6 , and $42.3 \%$, respectively, for 5,10 , and $15 \mathrm{~min}$ of glidarc exposure. For 5, 10, and 15 min of plasma-chemical oxidation, the color abatements by 70 , 95, and $100 \%$, respectively, were obtained for 6-h biodegradation, and the bleaching rate enhancements were 41.5, 53.6, and $50.3 \%$, respectively.

The high color abatement values could be explained by the cumulative effects of plasma-pre-treatment and biodegradation, and by the formation of more biodegradable by-products: for example, $\mathrm{DBO}_{5} / \mathrm{COD}=0.23$ for $t^{*}=15 \mathrm{~min}$ higher than 0.11 for $t^{*}=0 \mathrm{~min}$.

The color removal of $\mathrm{CV}$ solution was not significant enough $(70 \%)$ at the end of plasma glidarc/biodegradation coupling of the 5-min pre-treated sample: This is due to the poor biodegradability of $\mathrm{CV}$ solution after $5 \mathrm{~min}$ of plasma-chemical oxidation $\left(\mathrm{DBO}_{5} / \mathrm{COD}=0.13\right)$, given that there is a small amount of biodegradable by-products in solution. García-Montaño et al. (2006) achieved $100 \%$ of color abatement for a long biological treatment time (48 h) during the removal of hetero-bireactive dye by the combination of photo-Fenton process and aerobic sequencing batch reactor.

AOPs generally enhance a biodegradation process, because AOPs are able to convert recalcitrant compounds to biodegradable by-products. The degradation of malachite green (TPM dye) by the electro-Fenton process yields biodegradable by-products (Oturan et al. 2008). The results of this study corroborate those of Ballesteros et al. (2009) on pesticides degradation by photo-Fenton oxidation/ biodegradation coupling. These authors demonstrated that pesticides mineralized at $31 \%$ by photocatalytic pretreatment could be completely mineralized for 5-h biological treatment.

\section{Comparison of glidarc plasma/biodegradation coupling with post-discharge}

The bleaching rates of $\mathrm{CV}$ treated by the different methods used in this study are presented in Fig. 10. For 5, 10, and 15 min of direct exposure of $\mathrm{CV}$ to glidarc, the bleaching rates were $28.5,41.4$, and $49.7 \%$, respectively. For these exposure times $t^{*}(5,10$, and $15 \mathrm{~min}), 2$-h TPDR led to abatements of 39,60 , and $55 \%$, respectively, whereas $2-\mathrm{h}$ biological treatment led to 60, 84, and $92 \%$ bleaching rates, respectively, after 5-, 10-, and 15-min glidarc exposure. As already mentioned, temporal post-discharge increases the bleaching rates, but the results obtained in 


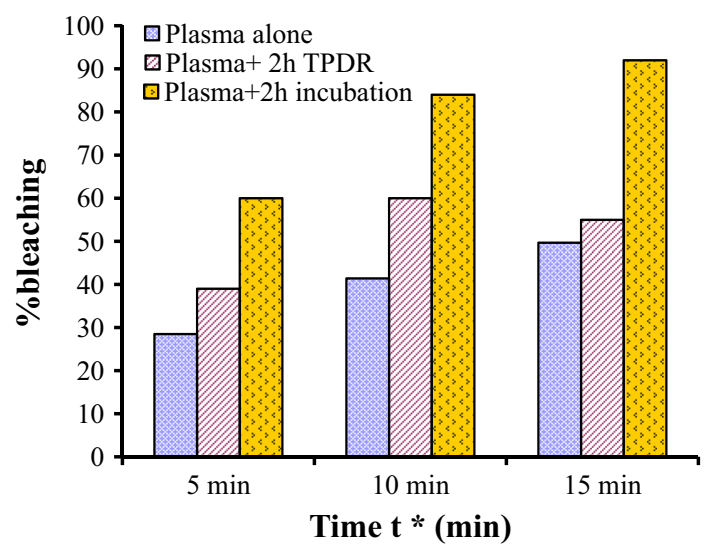

Fig. 10 Comparison of glidarc plasma/biodegradation coupling and temporal post-discharge treatment of $\mathrm{CV}($ A. hydrophila $)=0.8 \times$ $10^{9} \mathrm{CFU} \mathrm{mL}{ }^{-1}, T=37^{\circ} \mathrm{C}, \mathrm{pH} 7.5$

this study evidence a better enhancement when the biological process was coupled with glidarc pre-treatment. These results justify the use and the efficiency of glidarc plasma/biodegradation coupling for the treatment of textile wastewater.

\section{Conclusion}

This paper reports on the ability of gliding arc discharge to enhance the biodegradation of a TPM dye by A. hydrophila strain. The results showed that $A$. hydrophila strain in the stationary growth phase bleaches $42 \%$ of CV $\left(50 \mathrm{mg} \mathrm{L}^{-1}\right)$ for 12 -h incubation at $37{ }^{\circ} \mathrm{C}$. Biodegradation of $\mathrm{CV}$ by $A$. hydrophila follows pseudo-first-order kinetics. Bleaching and degradation of CV by plasma glidarc obey a pseudofirst-order kinetic with rate constants of $4.2 \times 10^{-2}$ and $1.4 \times 10^{-2} \mathrm{~min}^{-1}$, respectively. For 30 -min exposure to the plasma, $67 \%$ of color removal was obtained, while COD abatement was $35 \%$. Post-discharge kinetics abatement also followed pseudo-first-order kinetics. The results have shown that 15 min of glidarc plasma treatment is the optimal pre-treatment time: Biodegradability index $\mathrm{DBO}_{5} /$ COD of water polluted by the CV increases from 0.11 to 0.23 , while mineralization was only by $12.2 \%$. For this time, bleaching rate was $49.7 \%$, and after $2 \mathrm{~h}$ in TPDR, this rate increased to $55 \%$, and when the biological process was coupled, the bleaching rate was $92 \%$ for 2-h incubation and $100 \%$ bleaching was achieved for 6-h incubation. The glidarc plasma/biodegradation coupling increases the efficiency of the wastewater treatment and reduces the biodegradation time. There is a positive synergism of bacterial and plasma treatments. This coupling also reduces energy cost associated with complete mineralization of wastewater by nonthermal plasma processes.
Acknowledgments The authors thank the International Foundation of Sciences (IFS) for the provision of equipment through the scholarship (No.: W/4219-1) granted to Mr. Serge Nzali. The authors also thank the Laboratory of Experimental Bacteriology of Centre Pasteur du Cameroun, for their contribution in analysis. Special thanks to "Laboratoire d'Electrochimie Interfaciale et de Chimie Analytique" of University of Rouen (France) for the collaboration and to have offered us the plasma reactor and the TOC analyzer used in this study.

\section{References}

Abdelmalek F, Ghezzar MR, Belhadj M, Addou A, Brisset JL (2006) Bleaching and degradation of textile dyes by non-thermal plasma process at atmospheric pressure. Ind Eng Chem Res 45:23-29

Abdelmalek F, Torres RA, Combet E, Petrier C, Pulgarin C, Addou A (2008) Gliding arc discharge (GAD) assisted catalytic degradation of bisphenol A in solution with ferrous ions. Sep Purif Technol 63:30-37

Arab CM, Bagherian G, Bahramian B, Fahimi RB (2015) Synthesis and application of multiple rods gold-zinc oxide nanostructures in the photocatalytic degradation of methyl orange. Int J Environ Sci Technol 12:151-160

Asha A, Keerthi Muthukrishnaraj A, Balasubramanian N (2014) Improvement of biodegradability index through electrocoagulation and advanced oxidation process. Int J Ind Chem 5:4. doi:10. 1007/s40090-014-0004-x

Ballesteros MMM, Sánchez Pérez JA, Casas López JL, Oller I, Malato RS (2009) Degradation of a four-pesticide mixture by combined photo-Fenton and biological oxidation. Water Res 43:653-660

Benstaali B, Boubert P, Chéron BG, Addou A, Brisset JL (2002) Density and rotational temperature measurements of the NO and $\mathrm{OH}$ radicals produced by a gliding arc in humid air and their interaction with aqueous solutions. Plasma Chem Plasma Process 22:553-571

Brisset JL, Moussa D, Doubla A et al (2008) Chemical reactivity of discharges and temporal post-discharges in plasma treatment of aqueous media: examples of gliding discharges treated solutions. Ind Eng Chem Res 47:5761-5781

Chen KC, Wu JY, Liou DJ, Hwang SCJ (2003) Decolorization of the textile dyes by newly isolated bacterial strains. J Biotechnol 101(1):57-68

Chiing-Chang C, Hung-Ju L, Chiu-Yu C, Chia-Yuen Y, Ying-Chien C (2007) Biodegradation of crystal violet by Pseudomonas putida. Biotechnol Lett 29:391-396

Chimezie JO, Sawidis T (2011) Bioremediation and detoxification of synthetic wastewater containing triarylmethane dyes by Aeromonas hydrophila isolated from industrial effluent. Biotechnol Res Int. doi:10.4061/2011/967925

Clesceri LS, Greenberg AE, Eaton AD (2005) Standard methods for the examination of water and wastewater, 21st edn. American Public Health Association (APHA), Washington

Deng D, Guo J, Zeng G, Sun G (2008) Decolorization of anthraquinone, triphenylmethane and azo dyes by a new isolated Bacillus cereus strain DC11. Int Biodeterior Biodegrad 62:263-269

Djepang SA, Laminsi S, Njoyim-Tamungang E, Ngnintedem C, Brisset JL (2014) Plasma-chemical and photo-catalytic degradation of bromophenol blue. Chem Mater Eng 2(1):14-23

Doubla A, Bouba Bello L, Fotso M, Brisset JL (2008) Plasmachemical decolourisation of bromothymol blue by gliding electric discharge at atmospheric pressure. Dyes Pigment 77:118-124

Durai G, Rajasimman M, Rajamohan N (2011) Kinetic studies on biodegradation of tannery wastewater in a sequential batch bioreactor. J Biotech Res 3:19-26 
Farre MF, Franch MI, Malato S, Ayllon JA, Peral J, Domenech X (2005) Degradation of some biorecalcitrant pesticides by homogeneous and heterogeneous photocatalytic ozonation. Chemosphere 58:1127-1133

Feng Z, Kunyan C, Xiangdong L, Jiamo F, Guoying S (2004) Biodegradation kinetic of phthalate esters by Pseudomonas fluoresences FS1. Process Biochem 39:1125-1129

García-Montaño J, Torrades F, José A, García-Hortal Domènech X, Peral J (2006) Combining photo-Fenton process with aerobic sequencing batch reactor for commercial hetero-bireactive dye removal. Appl Catal B Environ 67:86-92

Goi A, Trapido M, Tuhkanen T (2004) A study of toxicity, biodegradability, and by-products of ozonised nitrophenols. Adv Environ Res 8:303-311

Gupta VK, Ali I, Saleh TA, Nayak A, Agarwal S (2012a) Chemical treatment technologies for waste-water recycling-an overview. RSC Adv 2:6380-6388

Gupta VK, Jain R, Mittal A, Saleh TA, Nayak A (2012b) Photocatalytic degradation of toxic dye amaranth on $\mathrm{TiO}_{2} / \mathrm{UV}$ in aqueous suspensions. Mater Sci Eng C 32:12-17

Huan-Jung F, Shiuh-Tsuen H, Wen-Hsen C (2009) Degradation pathways of crystal violet by Fenton and Fenton-like systems: condition optimization and intermediate separation and identification. J Hazard Mater 171:1032-1044

Iya-Sou D, Ognier S, Laminsi S, Cavadias S (2011) Specific role of active species created by gliding arc discharge for removal of persistent organic pollutants in aqueous solution: elimination mechanism. In: The 20th international symposium of plasma, Philadelphia, 24-29 July 2011

Kamgang-Youbi G, Herry JM, Bellon-Fontaine MN, Brisset JL, Doubla A, Naïtali M (2007) Evidence of temporal post-discharge decontamination of bacteria by gliding electric discharges : application of Hafnia alvei. Appl Environ Microbiol 73(15):4791-4796

Khenniche Favier L, Bouzaza A, Fourcade F, Aissani F, Amrane A (2015) Photocatalytic degradation of bezacryl yellow in batch reactors-feasibility of the combination of photocatalysis and a biological treatment. Environ Technol 36:1-10

Lesueur H, Czernichowski A, Chapelle J (1988) Dispositif de génération de plasma basse température par formation de décharges électriques glissantes (A device for generating a low temperature plasma by means of gliding electrical discharges). French Patent 88-2, 639, 172

Lontsi DC, Nola M, Tamsa AA, Nandjou NRV, Noah EOV, Nougang ML, Moungang ML (2013) Effect of disinfectants on adhered Aeromonas hydrophila to polyethylene immersed in water under static and dynamic conditions. Int J Res Biosci 2:33-48

Lotio AM, De Santis M, Rossetti S, Lopez A, Dilaconi C (2014) Onsite treatment of textile yarn dyeing effluents using an integrated biological-chemical oxidation process. Int J Environ Sci Technol 11:623-632

Mantzavinos D, Psillakis E (2004) Enhancement of biodegradability of industrial wastewaters by chemical oxidation pre-treatment. J Chem Technol Biotechnol Rev 79:431-454

Marchal N, Bourdon JL, Richard C (1991) Culture media for isolation and biochemical identification of bacteria. Doin Edition, Paris 509

Marco A, Esplugas S, Saum G (1997) How and why combine chemical and biological processes for wastewater treatment. Water Sci Technol 35(4):321-327

Merouani DR, Abdelmalek F, Ghezzar MR, Semmoud A, Addou A, Brisset JL (2013) Influence of peroxoynitrite in gliding arc discharge treatment of Alizarin red and post-discharge effect. Ind Eng Chem Res 52:1471-1480

Mittal A, Mittal J, Malviya A, Kaur D, Gupta VK (2010) Adsorption of hazardous dye crystal violet from wastewater by waste materials. J Colloid Interface Sci 343:463-473
Moturi B, Singaracharya MA (2009) Decolorization of crystal violet and malachite green by fungi. Sci World J 4:28-33

Moussa D, Doubla A, Kamgang-Youbi G, Brisset JL (2007) Postdischarge long life reactive intermediaites involved in the plasma chemical degradation of an azoic dye. IEEE Trans Plasma Sci 35:444-453

Naïtali M, Kamgang-Youbi G, Herry JM, Bellon-Fontaine MN, Brisset JL (2010) Combined effect of long-living chemical species during microbial inactivation using atmospheric plasmatreated water. Appl Environ Microbiol 76:7662-7664

Naïtali M, Herry JM, Hnatiuc E, Kamgang G, Brisset JL (2012) Kinetic and bacterial induced by peroxynitrite in electric discharges in air. Plasma Chem Plasma Process 32(4):675-692

Njoyim-Tamungang E, Ghogomu P, Laminsi S, Nzali S, Doubla A, Brisset JL (2009) Coupling gliding discharge treatment and catalysis by oyster shell powder for pollution abatement of surface waters. Ind Eng Chem Res 48:9773-9780

Ogugbue Chimezie J, Sawidis T, Oranusi NA (2012) Bioremoval of chemically different synthetic dyes by Aeromonas hydrophila in simulated wastewater containing dyeing auxiliaries. Ann Microbiol 62(3):1141-1153

Oturan MA, Guivarch E, Oturan N, Sirés I (2008) Oxidation pathways of malachite green by $\mathrm{Fe}^{3+}$-catalysed electro-Fenton process. Appl Catal B Environ 82:244-254

Parshetti GK, Parshetti SG, Telke AA, Kalyani DC, Doong RA, Govindwar SP (2011) Biodegradation of crystal violet by Agrobacterium radiobacter. J Environ Sci 23(8):1384-1393

Rajesh KS, Uttam CB (1999) Decolorization of triphenylmethane dyes and textile and dyes-stuff effluent by Kurthia sp. Enzym Microb Technol 24:433-437

Ren S, Guo J, Zeng G, Sun G (2006a) Decolorization of triphenylmethane, azo and anthraquinone dyes by a newly isolated Aeromonas hydrophila strain. Appl Microbiol Biotechnol 72:1316-1321

Ren SZ, Guo JY, Wang L, Cen YH, Sun GP (2006b) Properties of triphenylmethane dyes decolorization enzyme TpmD from Aeromonas hydrophila strain DN322. Acta Microbiol Sin 46:385-389

Rodier J, Bazin C, Broutin JP, Chambon P, Champsaur H, Roch L (1996) L'analyse de l'eau : eaux naturelles, eaux résiduaires, eaux de mer, 8e edition. DUNOD, Paris, pp 346-355

Saleh TA, Gupta VK (2012) Photo-catalyzed degradation of hazardous dye methyl orange by use of a composite catalyst consisting of multi-walled carbon nanotubes and titanium dioxides. J Colloid Interface Sci 371:101-106

Saleh TA, Al-Saadi AA, Gupta VK (2014) Carbonaceous adsorbent prepared from waste tires: experimental and computational evaluations of organic dye methyl orange. J Mol Liq 191:85-91

Sani RK, Banerjee UC (1999) Decolorization of triphenylmethane dyes and textile and dye-stuff effluent by Kurthia sp. Enzyme Microb Technol 24:433-437

Siciliano A, De Rosa S (2015) Experimental formulation of a kinetic model describing the nitrification process in biological aerated filters filled with plastic elements. Environ Technol 36:293-301

Sun-Young A, Sang-Ki M, In-Ho C, Yong-Lark C, Young-Su C, Cherol-Ho K, Young-Choon L (2002) Decolorization of triphenylmethane and azo dyes by Citrobacter sp. Biotechnol Lett 24:1037-1040

Vilar VJP, Moreira FC, Ferreira ACC et al (2012) Biodegradability Enhancement of pesticide-containing bio-treated wastewater using a solar photo-Fenton treatment step followed by a biological process. Water Res 46:4599-4613

Young L, Yu J (1997) Ligninase catalysed decolorization of synthetics dyes. Water Res 31:1187-1193

Yousefi Kebria D, Khodadadi A, Gaujidoust H, Badkoubi A, Amoozegar MA (2009) Isolation and characterization of a novel 
native Baccilus strain capable of degrading diesel fuel. Int $\mathbf{J}$ Environ Sci Technol 6(3):435-442

Zapata A, Oller I, Sirtori C et al (2010) Decontamination of industrial containing pesticides by combining large-scale homogeneous solar photocatalysis and biological treatment. Chem Eng J 160(2):447-456
Zhou W, Zimmermann W (1993) Decolorization of industrial effluents containing reactive dyes by actinomycetes. FEMS Microbiol Lett 107:157-162 